\title{
Dihaploid plants of roses (Rosa $x$ hybrida, cv 'Sonia') obtained by parthenogenesis induced using irradiated pollen and in vitro culture of immature seeds
}

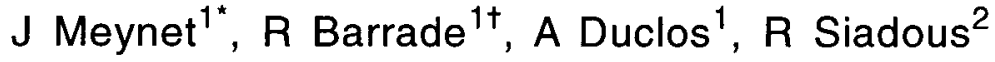 \\ 'INRA, Station d'Amélioration des Plantes Florales, La Gaudine, F83370 Saint-Aygulf; \\ ${ }^{2}$ Commissariat à l'Énergie Atomique, Service de Radioagronomie, CEN de Cadarache, F13108 Saint-Paul-lez-Durance, \\ Cedex, France
}

(Received 30 September 1993; accepted 10 January 1994)

\begin{abstract}
Summary - 'Sonia' var rose ovules produced plants through in vitro culture after being pollinated with irradiated (gamma rays) pollen. A 500-Gy minimum dose was sufficient to inactivate pollen and induce in situ parthenogenesis; in vitro culture was necessary for embryo rescue. The dihaploid plants originated from small embryos which occupied only a part of the carpel cavity; they were clearly distinguished from tetraploid plants by miniaturization of all organs. The dihaploid plants were observed under glass-house conditions until flowering presented a normal gynoecium. They produced a small amount of pollen of reduced but regular size; growth and development were faster than the tetraploid controls in summer.
\end{abstract}

haploidy/Rosa $x$ hybrida/pollen irradiation/gamma rays

Résumé - Obtention de plantes dihaploïdes de rosier (Rosa x hybrida, cv "Sonia") après parthénogenèse induite par l'emploi de pollen irradié et culture in vitro de graines immatures. Des ovules de rosier, variété "Sonia", cultivés in vitro après pollinisation avec du pollen irradié aux rayons gamma ont évolué en plantes entières. Le pollen inactivé efficace pour induire une parthénogenèse in situ doit subir une dose minimale de 500 Gy et la culture in vitro paraît indispensable pour assurer la survie des embryons. Les plantes dihaploïdes proviennent de petits embryons n'occupant qu'une partie de la cavité carpellaire, elles se distinguent nettement des tétraploïdes par une miniaturisation de tous les organes. Les plantes dihaploïdes observées en serre jusqu'à leur floraison présentent un gynécée normal, elles ne produisent que très peu de pollen d'un diamètre réduit mais régulier. La croissance et le développement de ces plantes sont plus rapides en été que ceux de plantes tétraploïdes témoins.

haploïdie/Rosa $x$ hybrida/irradiation de pollen/rayons gamma

\section{INTRODUCTION}

Modern roses with constant flowering belong to Rosa $x$ hybrida $(2 n=4 x=28)$ generally considered an autotetraploid species
(Berninger, 1992). Although this is commercially one of the major species that undergo selection processes, the genetic structure and the heredity of its traits remain unclear. On the other hand, new objectives of selection aim at obtaining an insect- and dis-

\footnotetext{
* Correspondence and reprints.

$\dagger$ Deceased.

Abbreviations: NAA: naphthaleneacetic acid; BA: 6-benzylaminopurine; K: kinetin; IBA: indolbutyric acid.
} 
ease-resistant or tolerant material. Hence, botanic diploid germplasm can be used as the genetic source. Finally, the present tetraploid level, the result of 200 years of uncontrolled interspecific crossing is not necessarily the best ploidy level for breeding efficiency. For all these reasons, it is important to obtain and analyse the dihaploid $(2 n=2 x=14)$ of cultivated roses, since this work has never been undertaken before.

Tabaeizadeh and Khosh-Khui (1981) obtained only haploid calluses from in vitro culture of $R$ damascena and $R$ hybrida anthers. The diploid roses produced by ReimannPhilipp (1981) after backcrossing of the triploid ( $R$ multiflora $\times R$ hybrida) with $R$ multiflora $(2 n=14)$ were both genetically and phenotypically closer to the diploid parent, in spite of the genetic exchange between the initial parents, as indicated by the author.

The above results show that we need a new method of haploidization. In our work, we associated parthenogenesis induced by the use of irradiated pollen and embryo rescue by in vitro culture. This combined method of haploidization was first developed by Pandey and Phung (1982) on different species of Nicotiana and by Raquin (1985) on Petunia. Sauton and Dumas de Vaulx (1987), Doré (1989) and Zhang et al (1988) successfully applied this method to musk melon, cabbage and apple, respectively.

\section{MATERIALS AND METHODS}

The 'Sonia' variety was chosen as the female parent because of its ability to flower in all seasons, and its high productivity of seeds. Pollen was collected on a mixture of cultivated genotypes since no morphological markers could be used to definitively distinguish dihaploids from hybrids. The donors were cultivated on perlite substratum under glass-houses which were maintained at least $14^{\circ} \mathrm{C}$ and opened at $22^{\circ} \mathrm{C}$. The anthers removed just before anthesis were placed in Petri dishes in a ventilated drying-room at $27^{\circ} \mathrm{C}$ for 24 $h$ and powdered pollen was then used immediately for experimentation.

\section{Irradiation and pollination}

Collected pollen was subjected to gamma rays using a Cobalt 60 source. Treatment was performed at the Centre de Cadarache on the following dates:

- 4 doses $(0,500,1000,1500$ and $2000 \mathrm{~Gy})$ on May 26, 1992;
- 3 doses $(0,250,500$, and 750 Gy) on July 2, 1992.

The flow rate of gamma rays was $33.5 \mathrm{~Gy} / \mathrm{min}$ for the $250 \mathrm{~Gy}$ dose and $150 \mathrm{~Gy} / \mathrm{min}$ for all the other doses.

The half-open flowers were emasculated and isolated $1 \mathrm{~d}$ before pollen irradiation. Pollination was carried out in saturating quantities during the warm hours of the afternoon on the day of pollen irradiation and the following day. After being pollinated, the flowers remained covered for $10 \mathrm{~d}$. For each trial, control flowers were pollinated by nonirradiated pollen. Pollen germination was tested in vitro on a solidified medium as used by Gudin et al (1991).

\section{Embryo rescue and in vitro culture}

The protocol of this work was based on a preliminary experiment conducted in 1991 on in vitro culture of immature embryos (unpublished results). In 1992, the fruits were collected on 2 dates, 21 and $35 \mathrm{~d}$ after pollination.

The hips collected after $21 \mathrm{~d}$ were soaked in $70 \%$ ethanol for $30 \mathrm{~s}$ and then $20 \mathrm{~min}$ in calcium hypochloride $\left(15 \mathrm{~g} \cdot \mathrm{I}^{-1}\right)$, followed by 2 rinses in sterile water. The fruit were then aseptically opened and only enlarged ovules were removed. One half of the ovules was placed directly in culture, whereas the other half was dissected under the binocular microscope and placed in culture without the tegument.

The fruits obtained $35 \mathrm{~d}$ after pollination were opened, the collected seeds were disinfected in the same way as the hips and put in culture without dissection. The pericarp was already lignified so that extraction of the embryos was very difficult.

The seeds were placed on MS400 a Murashige and Skoog's (1962) medium modified to half strength, with $400 \mathrm{mg} \cdot \mathrm{I}^{-1}$ ammonium nitrate instead of $1650 \mathrm{mg} \cdot \mathrm{I}^{-1}$ and supplemented with $5 \%$ sucrose. They were randomly distributed on 4 different hormone combinations:

I $0.27 \mu \mathrm{M} \cdot \mathrm{I}^{-1} \mathrm{NAA}+2.22 \mu \mathrm{M} \cdot \mathrm{I}^{-1} \mathrm{BA}$

II $0.54 \mu \mathrm{M} \cdot \mathrm{I}^{-1} \mathrm{NAA}+8.87 \mu \mathrm{M} \cdot \mathrm{I}^{-1} \mathrm{BA}$

III $0.27 \mu \mathrm{M} \cdot \mathrm{l}^{-1} \mathrm{NAA}+2.32 \mu \mathrm{M} \cdot \mathrm{l}^{-1} \mathrm{~K}$

IV $0.54 \mu \mathrm{M} \cdot \mathrm{I}^{-1} \mathrm{NAA}+9.29 \mu \mathrm{M} \cdot \mathrm{I}^{-1} \mathrm{~K}$

In each $5.5 \mathrm{~cm}$ Petri dish, a maximum of 5 seeds were placed, and then the dish was closed with a plastic film and left in the dark at $27^{\circ} \mathrm{C}$. After 3 months the embryos extracted from seeds were cultured on medium I with a $16 \mathrm{~h}$ photoperiod $\left(35 \mu \mathrm{mol} \cdot \mathrm{m}^{-2} \cdot \mathrm{s}^{-1}\right)$. The plants obtained were multiplied on a solid MS 400 medium supplemented with $3 \%$ sucrose and $2.22 \mu \mathrm{M} \cdot \mathrm{I}^{-1} \mathrm{BA}$.

In vitro rooting took place in Sorbarods (cellulose transplantation plugs from Baumgartner Papiers SA Lausane, Switzerland) saturated with 
basal liquid medium ( $6 \mathrm{ml} / \mathrm{tube}$ ) enriched with $2.46 \mu \mathrm{M} \cdot \mathrm{I}^{-1}$ IBA. The rooted plants were then transferred to the glass house on rockwool cubes.

\section{In situ matured fruit and seeds}

Some fruits were left in situ until complete maturity, and their seeds germinated according to the technique devised by Gudin et al (1990).

\section{Observation of plants obtained}

The chromosome number was checked on root tips, using the same method as described by Lespinasse and Salesses (1973) for apples and pears. The specific characteristics of the different ploidy levels were detected by cytological and morphological measures.

\section{RESULTS}

\section{The influence of irradiation on the germination of pollen and development of fruit and seeds}

Pollen put in culture on the day of irradiation germinated at $15-20 \%$ except for the one irradiated at $2000 \mathrm{~Gy}$, which reached $5 \%$ and produced shorter tube growth. After $3 \mathrm{~d}$ under laboratory conditions all pollen had germinated except that irradiated at 2000 Gy.

One of the effects of pollen irradiation was the yellowing and drying of the fruit, which started after the third week of pollination (table I).

Ovule enlargement was observed between the 21st and the 28th day, while on the 35th day all the ovules had enlarged and the pericarp was considerably lignified. All the fruit examined contained seeds, in spite of the different irradiation doses (table 1). However the number of seeds $(N)$ varied with the dose $(D)$ following a linear model for the different experimental doses.

$$
N=-0.00399 D+12.2, r=-0.89 \text { after }
$$
$21 \mathrm{~d}$ and

$$
N=-0.00441 \mathrm{D}+17.0, r=-0.91 \cdot \text { after }
$$
$35 \mathrm{~d}$.

The number of seeds was correlated directly with fruit diameter, $r=0.59$ after $21 \mathrm{~d}$ and $r=0.84$ after $35 \mathrm{~d}$, and especially with fruit weight, $r=0.81$ after $21 \mathrm{~d}$ and $r=0.96$ after $35 \mathrm{~d}$.

The size of the seeds extracted from mature fruit varied considerably with the various pollen treatments (fig 1 ). Only the control and the seeds resulting from pollination with 250 -

Table I. Number and characteristics of collected fruits and enlarged seeds obtained after different doses

\begin{tabular}{|c|c|c|c|c|c|c|c|}
\hline $\begin{array}{c}\text { Time } \\
\text { of fruit } \\
\text { collection }\end{array}$ & $\begin{array}{c}\text { Dose of pol- } \\
\text { len irradia- } \\
\text { tion (Gy) }\end{array}$ & $\begin{array}{c}\text { No } \\
\text { pollinated } \\
\text { flowers }\end{array}$ & $\begin{array}{c}\text { No } \\
\text { collected } \\
\text { fruits }\end{array}$ & $\begin{array}{c}\text { Average } \\
\text { fruit weight } \\
\text { (g) }\end{array}$ & $\begin{array}{c}\text { Average } \\
\text { fruit diame- } \\
\text { ter }(\mathrm{cm})\end{array}$ & $\begin{array}{c}\text { No en- } \\
\text { larged seeds }\end{array}$ & $\begin{array}{c}\text { No seeds } \\
\text { No fruit } \\
\text { collected }\end{array}$ \\
\hline \multirow[t]{7}{*}{$21 d$} & 0 & 16 & 13 & 2.81 & 1.36 & 185 & 14.2 \\
\hline & 250 & 8 & 7 & & & 76 & 10.9 \\
\hline & 500 & 16 & 11 & 2.45 & 1.32 & 100 & 9.1 \\
\hline & 750 & 8 & 6 & & & 41 & 6.8 \\
\hline & 1000 & 8 & 5 & 2.48 & 1.38 & 50 & 10 \\
\hline & 1500 & 8 & 3 & 2.17 & 1.27 & 22 & 7.3 \\
\hline & 2000 & 8 & 3 & 2.31 & 1.31 & 13 & 4.3 \\
\hline \multirow[t]{7}{*}{$35 d$} & 0 & 14 & 11 & 4.51 & 1.71 & 230 & 20.9 \\
\hline & 250 & 7 & 5 & & & 86 & 17.2 \\
\hline & 500 & 14 & 8 & 3.21 & 1.65 & 108 & 13.5 \\
\hline & 750 & 7 & 3 & & & 34 & 11.3 \\
\hline & 1000 & 7 & 4 & 2.12 & 1.45 & 48 & 12 \\
\hline & 1500 & 7 & 2 & 2.41 & 1.38 & 23 & 11.5 \\
\hline & 2000 & 7 & 1 & 2.31 & 1.51 & 9 & 9 \\
\hline \multirow[t]{7}{*}{ Maturity } & 0 & 12 & 8 & & & 163 & 20.4 \\
\hline & 250 & 5 & 3 & & & 41 & 13.7 \\
\hline & 500 & 12 & 4 & & & 50 & 12.5 \\
\hline & 750 & 5 & 2 & & & 13 & 6.5 \\
\hline & 1000 & 7 & 3 & & & 22 & 7.3 \\
\hline & 1500 & 7 & 2 & & & 25 & 12.5 \\
\hline & 2000 & 7 & 1 & & & 2 & 2 \\
\hline
\end{tabular}
of pollen irradiation".

*Total of 2 trials: irradiation and pollination on May 26 and July 2, 1992 


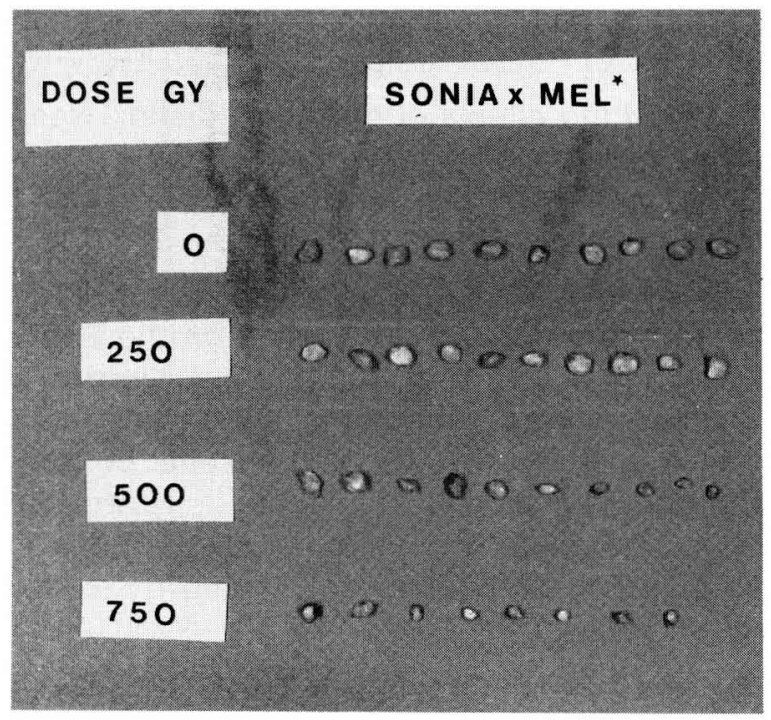

Fig 1. Effect of different irradiation doses of pollen on the size of seeds collected from mature fruit.

Table II. Effect of irradiation doses on the seeds collected at fruit maturity.

\begin{tabular}{ccc}
\hline Dose (Gy) & $\begin{array}{c}\text { No seeds/ } \\
\text { No fruit }\end{array}$ & Germination \% \\
\hline 0 & $163 / 8$ & 43 \\
250 & $41 / 2$ & 14 \\
500 & $50 / 4$ & 0 \\
750 & $13 / 2$ & 0 \\
1000 & $22 / 3$ & 0 \\
1500 & $25 / 2$ & 0 \\
2000 & $2 / 1$ & 0 \\
\hline
\end{tabular}

*Total of 2 trials.
Gy-irradiated pollen germinated with a success of 43 and $14 \%$, respectively (table II).

\section{Immature embryo rescue in vitro}

The nature of the difficulties encountered differed with the stage of sampling. The percentage of germination with control ovules was $9.2 \%$ on average, and was $13.8 \%$ for intact ovules, and only $4.4 \%$ for ovules stripped of their teguments. The percentage of success observed for control seeds $35 \mathrm{~d}$ after pollination was better $(23 \%)$, but was followed by fungal contamination identified as Alternaria in about $50 \%$ of the material.

Embryos were observed in all test samples, except those treated with 2000-Gyirradiated pollen. The embryos resulting from pollen irradiated at 500 Gy and above were 2-4-fold shorter than those resulting from control or 250-Gy-treated pollen, where the embryo occupied all the carpel cavity.

Embryos germinated on all the media tested; the data showed no effect of the different hormone combinations.

In some cases 3 sub-cultures on medium I were necessary to obtain green cotyledons followed by the appearance of the first leaf and elongation of the seed root. Thus, we obtained (table III) 59 plants from control pollen, 1 plant from 250 Gy, 3 plants from 500 Gy, 1 plant from 750 Gy and 2 plants from 1500 Gy.

Table III. Results of in vitro culture of immature seeds.

\begin{tabular}{|c|c|c|c|c|c|}
\hline $\begin{array}{l}\text { Time of fruit } \\
\text { collection }\end{array}$ & $\begin{array}{l}\text { Dose of } \\
\text { irradiation }\end{array}$ & $\begin{array}{l}\text { No collected } \\
\text { seeds }\end{array}$ & $\begin{array}{c}\text { No cultivated seeds } \\
(\% \text { contamin })\end{array}$ & $\begin{array}{l}\text { No cotyledona- } \\
\text { ry embryos }\end{array}$ & No plantlets \\
\hline \multirow[t]{7}{*}{$21 d$} & 0 & 185 & $185(0 \%)$ & 17 & 16 \\
\hline & 250 & 76 & $76(0 \%)$ & 1 & 1 \\
\hline & 500 & 100 & $100(0 \%)$ & 1 & 1 \\
\hline & 750 & 41 & $41(0 \%)$ & 1 & 1 \\
\hline & 1000 & 94 & $94(0 \%)$ & 0 & 0 \\
\hline & 1500 & 22 & $22(0 \%)$ & 0 & 0 \\
\hline & 2000 & 13 & $13(0 \%)$ & 0 & 0 \\
\hline \multirow[t]{7}{*}{$35 d$} & 0 & 230 & $113(51 \%)$ & 52 & 43 \\
\hline & 250 & 86 & $39(55 \%)$ & 2 & 0 \\
\hline & 500 & 108 & $51(53 \%)$ & 3 & 2 \\
\hline & 750 & 34 & $19(44 \%)$ & 0 & 0 \\
\hline & 1000 & 48 & $21(56 \%)$ & 1 & 0 \\
\hline & 1500 & 23 & $18(22 \%)$ & 2 & 2 \\
\hline & 2000 & 9 & $3(67 \%)$ & 0 & 0 \\
\hline
\end{tabular}

\footnotetext{
*Total of 2 trials.
} 


\section{Description of plants obtained}

The 250 Gy pollen produced 3 embryos in vitro and 6 seeds in situ that matured and germinated and then yielded only one plant for each condition (in situ and in vitro). These plants were similar to the control but their growth rate was slower, with some abnormalities (thick leaf blade, irregular leaflets, and absence of stigma in one case). The chromosome number of the tested plant was 28.

However, the 6 plants produced through pollination at $500 \mathrm{~Gy}$ and higher pollen irradiations had a different in vitro morphology from the control. When the first leaf appeared (fig 2), all organs, leaflets, petioles and stems had much smaller sizes. However, their multiplication rate was highly variable. Only one plant remained unable to root up to this point. In comparison with the control, the first 3 plants flowered at the same time and their summer growth and flowering were very active, but with smaller leaves and pollen, stoma length and chloroplast number in all

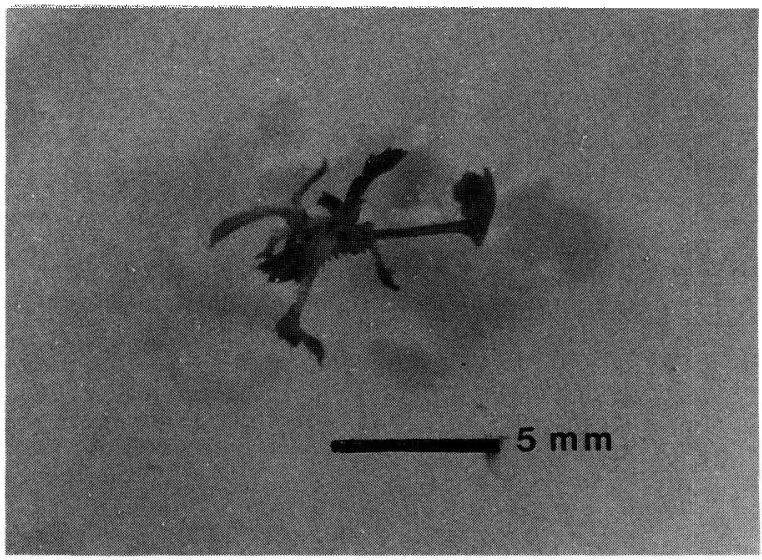

Fig 2. Young dihaploid plant after in vitro embryo rescue.
5 plants (fig 3 , table IV). The chromosome counts were often difficult. The dihaploid state $(2 n=2 x=14)$ was demonstrated on 2 plants (figs 4 and 5 ).

\section{DISCUSSION AND CONCLUSIONS}

All the plants obtained after pollination with pollen irradiated at 500 Gy and above have common morphological traits, which are classically used as ploidy indices; 2 have the diploid number of chromosomes. Consequently, the 500-Gy dose of pollen irradiation is sufficient to induce the parthenogenetic development of rose seeds.

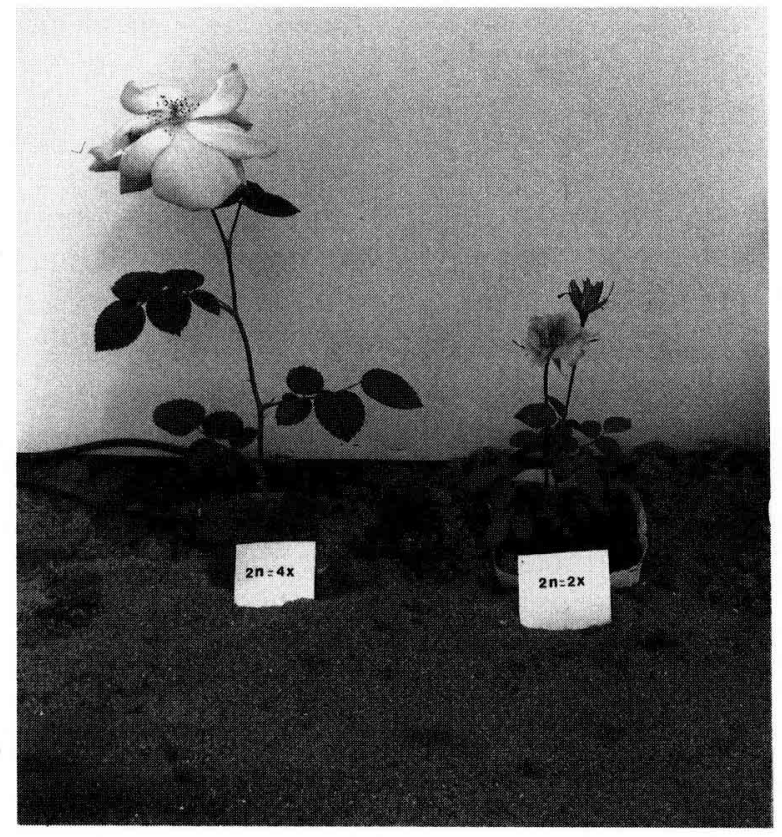

Fig 3. Synchronic flowering of 2 plants, one pollinated by control pollen (left $2 n=4 x$ ), the other by 500-Gy-irradiated pollen (right $2 n=2 x$ )

Table IV. Comparison of some characteristics of plants obtained after pollination by pollen irradiated at 500 Gy minimum with the tetraploid control ('Sonia' offspring).

\begin{tabular}{|c|c|c|c|c|c|c|c|}
\hline & \multicolumn{6}{|c|}{ Plants from irradiated pollen } & \multirow{2}{*}{ Tetraploid } \\
\hline & $1^{\mathrm{a}}$ & & 2 & $3^{\mathrm{a}}$ & 4 & 5 & \\
\hline Stoma length $\mathrm{mm}^{\mathrm{b}}$ & $22.7 \pm 4.4$ & 25 & \pm 4.32 & $24.2 \pm 3.6$ & $26.1 \pm 3.8$ & $23.1 \pm 4$ & $31.5 \pm 3.4$ \\
\hline Stoma width $\mathrm{mm}^{\mathrm{b}}$ & $26.1 \pm 7.8$ & 24.9 & \pm 6.4 & $25.1 \pm 5.8$ & $23.8 \pm 5$ & $24.5 \pm 8$ & $24 \pm 4.2$ \\
\hline Chloroplast number ${ }^{\mathrm{b}}$ & $16 \pm 4.4$ & 19.7 & \pm 7.4 & $19.1 \pm 6.6$ & $16.9 \pm 6$ & $16.3 \pm 5.6$ & $29.8 \pm 7.8$ \\
\hline Pollen diameter & $24 \pm 3.2$ & 26 & \pm 3 & $29 \pm 3.2$ & & & $43 \pm 5.6$ \\
\hline Leaf length ${ }^{c}$ & $65 \pm 15$ & 53 & \pm 9.2 & $77 \pm 11$ & & & $93.5 \pm 38.8$ \\
\hline Leaf width ${ }^{c}$ & $38 \pm 8.6$ & 29 & \pm 6 & $31 \pm 7.8$ & & & $65 \pm 34.4$ \\
\hline
\end{tabular}

${ }^{a} 28$ chromosomes have been counted in root-tips; ${ }^{b}$ first leaves initiated ex vitro ( 3 leaflets); ${ }^{c}$ first leaf with 5 leaflets. 


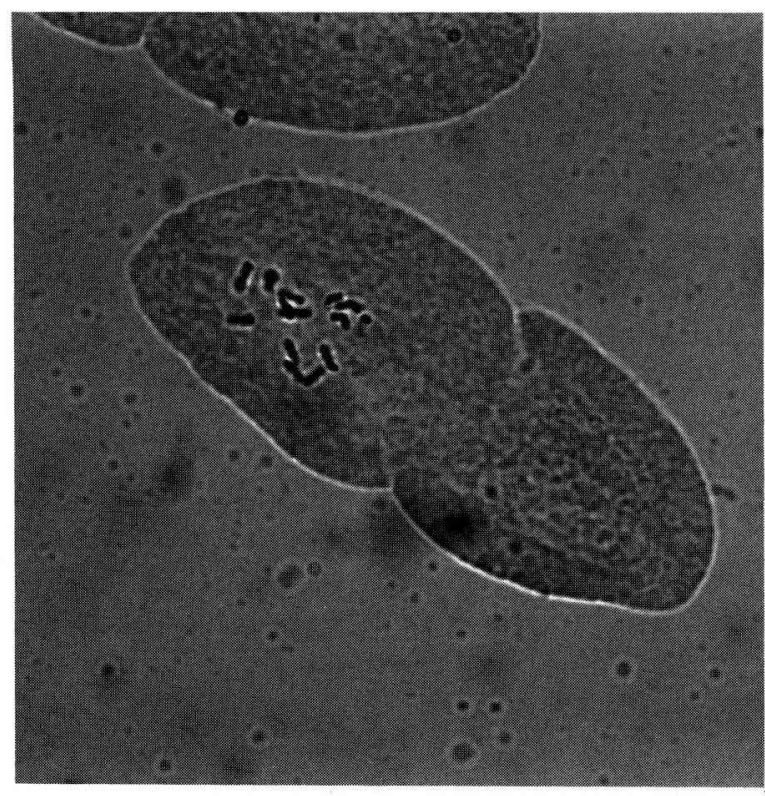

Fig 4. Mitosis in a dihaploid root tip.

Treatment at 250 Gy produced high mortality rates and very slow growth of plants. This established phenomenon is known as the 'Hertwig effect' (Pandey and Phung, 1982).

On the other hand, all pollen irradiated above 500 Gy and up to 2000 Gy gave mature fruit and enlarged ovules unlike apples where the flower fell after pollination with 1500-Gy-irradiated pollen (Zhang et al, 1988). Hence the pollen of Rosa hybrida appears less sensitive to irradiation than apple pollen.

The embryos and seeds developed and germinated in vitro under a constant temperature of $27^{\circ} \mathrm{C}$ with no cold treatment since there was no dormancy phase in our experimental conditions.

The percentage of diploid plants obtained in the first trial was 1.6 plants on average for 100 enlarged ovules in culture, and 6.7 plants for 100 flowers pollinated by inactivated pollen. Further optimization of the procedure should be followed giving priority to:

- increasing the number of seeds per fruit through testing of genotypic and physiological inductive factors occurring before and at the time of pollination;

- increasing the number of viable embryos in enlarged ovules by suitable horticultural growing conditions, especially just after pollination;

- improving in vitro embryo rescue, particularly by a better control of fungal contaminations.
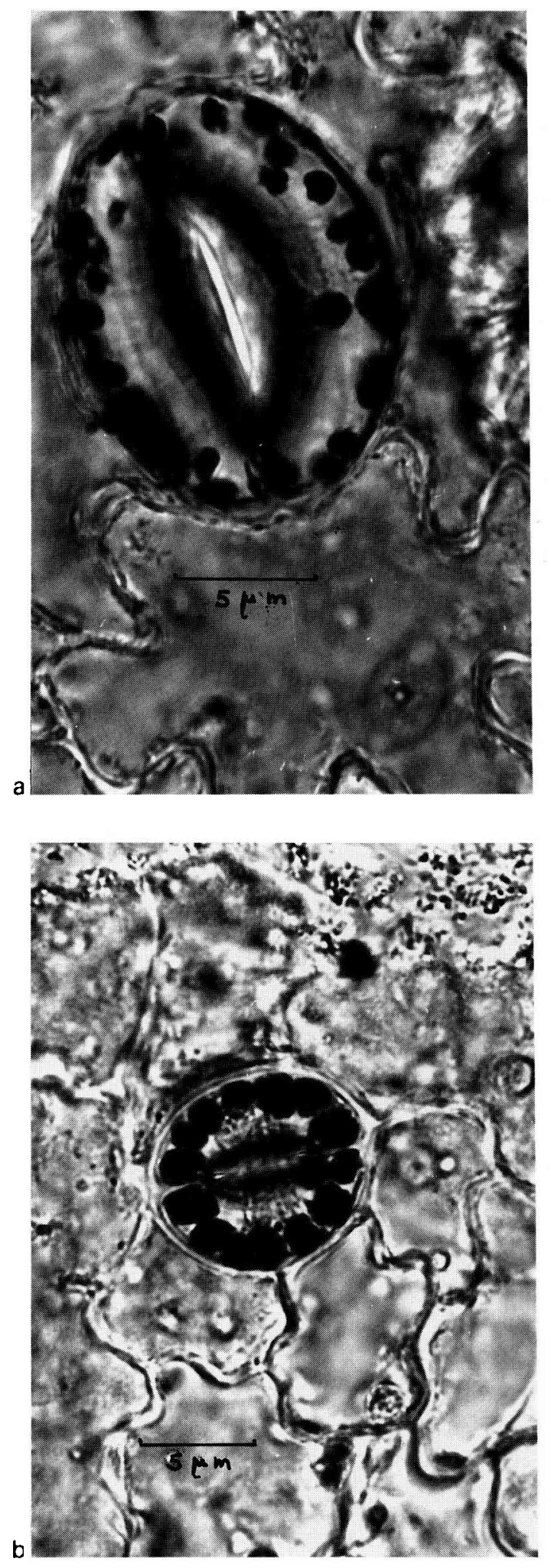

Fig 5. Stoma of tetraploid plant (a) and diploid (b) plant

The possibility of using the dihaploid material in selection programs depends on its fertility. Observation of the first flowers of a single plant throughout the summer and 2 
other plants in late summer did not help us verify this point.

The presence of a normal gynoecium and regular but rare pollen is rather encouraging.

\section{ACKNOWLEDGMENTS}

The authors thank $J$ Eychenne (student at INP, Toulouse) for her participation in the plant material observations, P Venard (INRA, Station de Pathologie, Antibes) who was kind enough to provide the microscope photos and L Kevorkian for translating this article into English.

\section{REFERENCES}

Berninger E (1992) Le rosier de serre pour fleurs à couper. In: Amélioration des espèces végétales cultivées (A Gallais, M Bannerot, eds) INRA, Paris, 490-504

Doré C (1989) Obtention de plantes haploïdes de chou cabus (Brassica oleracea L ssp capitata) après culture in vitro d'ovules pollinisés par du pollen irradié. CR Acad Sci Paris Sér III, 729-734

Gudin S, Arene L, Chavagnat A, Bulard C (1990) Influence of endocarp thickness on rose achene germination: genetic and environmental factors. Hortscience 25, 786-788
Gudin S, Arene L, Bulard C (1991) Influence of season on rose pollen quality. Sex Plant $R e$ prod 4, 113-117

Lespinasse Y, Salesses G (1973) Application de techniques nouvelles à l'observation des chromosomes chez les genres Malus et Pyrus. Ann Amélior Plantes 23, 381-386

Murashige T, Skoog F (1962) A revised medium for rapid growth and bio-assay with tobacco tissue cultures. Physiol Plant 15, 473-497

Pandey KK, Phung M (1982) 'Hertwig effect' in plants: induced parthenogenesis through the use of irradiated pollen. Theor Appl Genet 62, 295-300

Raquin C (1985) Induction of haploid plants by in vitro culture of petunia ovaries pollinated with irradiated pollen. Z Pflanzenzücht 94, 166-169

Reimann-Philipp R (1981) Cytogenetics and breeding in diploid roses from the triploid hybrid $R$ multiflora x garden cultivars. Eucarpia Meeting on Rose Breeding, Ahrensburg, 7-8 September, $27-29$

Sauton A, Dumas de Vaulx R (1987) Obtention de plantes haploïdes chez le melon (Cucumis melo L) par gynogenèse induite par du pollen irradié. agronomie $7,141-148$

Tabaeizadeh Z, Khosh-Khui M (1981) Anther culture of Rosa. Sci Hortic 15, 61-66

Zhang YX, Lespinasse $Y$, Chevreau E (1988) Obtention de plantes haploïdes de pommier (malus $\times$ domestica Borlch) issues de parthénogenèse induite in situ par du pollen irradié et culture in vitro des pépins immatures. CR Acad Sci Paris, Sér III 451-457 